\title{
Study on the Formation of Secondary Organic Aerosol by Ozonolysis of Citral in the Atmosphere
}

Aerosol and Air Quality Research

\section{OPEN ACCESS}

Received: November 19, 2020

Revised: February 18, 2021

Accepted: March 2, 2021

\author{
${ }^{*}$ Corresponding Authors: \\ Chenxi Zhang \\ sdzhangcx@163.com \\ Hengjun Peng \\ phj@sdu.edu.cn
}

\section{Publisher:}

Taiwan Association for Aerosol Research

ISSN: $1680-8584$ print

ISSN: 2071-1409 online

(c) Copyright: The Author(s).

This is an open access article distributed under the terms of the Creative Commons Attribution License (CC BY 4.0), which permits unrestricted use, distribution, and reproduction in any medium, provided the original author and source are cited.

\author{
Chenxi Zhang ${ }^{1,2^{*}}$, Xuesong $\mathrm{Cao}^{2}$, Xiaomin Sun ${ }^{2}$, Hengjun Peng ${ }^{3^{*}}$ \\ ${ }^{1}$ College of Biological and Environmental Engineering, Binzhou University, Binzhou 256600, \\ China \\ ${ }^{2}$ Environment Research Institute, Shandong University, Qingdao 266200, China \\ ${ }^{3}$ Logistics support department, Shandong University, Jinan 250100, China
}

\section{ABSTRACT}

A major research area in atmospheric chemistry focuses on the formation of secondary organic aerosol (SOA), which contains a large variety of low-volatility organic compounds when generated by the ozonolysis of monoterpenes. Thus, we apply quantum chemistry and kinetic calculations to investigate the ozonolysis of citral, which begins with the formation of primary ozonides (POZs) that decompose into Criegee intermediates (Cls). Although $\mathrm{Cls}$ have been previously implicated in tropospheric oxidation, the majority are simple compounds for their class, such as $\mathrm{CH}_{2} \mathrm{OO}$. or $\mathrm{CH}_{3} \mathrm{CHOO}$. This study, however, reports on the generation and reaction kinetics of larger $\mathrm{Cls}$, which have been shown to oxidize $\mathrm{NO}$ and $\mathrm{SO}_{2}$ into $\mathrm{NO}_{2}$ and $\mathrm{SO}_{3}$, respectively, leading to the production of nitric acid and sulfuric acid. Furthermore, the reactions between these $\mathrm{Cls}$, and $\mathrm{H}_{2} \mathrm{O}$ and $\mathrm{SO}_{2}$ may serve as the dominant mechanism for removing the former from the troposphere, thereby determining the atmospheric $\mathrm{Cl}$ concentrations. The low-volatility organic compounds potentially arising from the ozonolysis of citral, including aldehydes $(-\mathrm{C}(=\mathrm{O}) \mathrm{H})$, ketones $(-\mathrm{C}(=\mathrm{O})-)_{\text {, }}$ alcohols $(-\mathrm{OH})$, and hydroperoxides $(-\mathrm{OOH})$, can form SOA through the nucleation, condensation, and/or partitioning of the condensed and gaseous phases.

Keywords: Secondary organic aerosol, Citral, Ozonolysis, Criegee intermediates

\section{INTRODUCTION}

Atmospheric aerosols significantly affect the earth's radiation balance by absorbing and scattering solar radiation, leading to a decrease in atmospheric visibility and contributing to climate change. Moreover, due to the small particle size and large surface area of atmospheric aerosols, they provide a reaction bed for various atmospheric chemical processes and have a direct effect on human health (Oberdorster et al., 2005; Pope and Dockery, 2006). Atmospheric aerosols are mainly classified as either primary aerosols which are directly discharged into the atmosphere by an exhaust source, or secondary aerosols formed in the atmosphere from chemical reaction with gaseous components (Atkinson and Arey, 2003; Hallquist et al., 2009). Secondary organic aerosols (SOAs) are mainly formed from the oxidation processes of volatile organic compounds (VOCs) and account for a significant fraction of ambient tropospheric aerosols (Jimenez et al., 2009).

About $90 \%$ of the total global VOCs emissions that lead to SOAs formation come from biological sources, which including isoprene $\left(\mathrm{C}_{5} \mathrm{H}_{8}\right)$, monoterpenes $\left(\mathrm{C}_{10} \mathrm{H}_{16}\right)$, and sesquiterpenes $\left(\mathrm{C}_{15} \mathrm{H}_{24}\right)$ (Guenther et al., 1995; Goldstein and Galbally, 2007; Friedman and Farmer, 2018; Stangl et al., 2019). Monoterpenes have been found to be the largest contributors to organic aerosol during the summer in the southeastern United States, with mean global emissions estimated to be approximately 107.5 TgC per year (Messina et al., 2016; Zhang et al., 2018; Nagori et al., 2019). As monoterpenes are unsaturated, they rapidly react with $\mathrm{O}_{3}, \mathrm{OH}$ and $\mathrm{NO}_{3}$ radicals, with estimated reaction rates for $\mathrm{OH}$ and $\mathrm{NO}_{3}$ radicals with most monoterpenes being larger than $10^{-11}$ $\mathrm{cm}^{3}$ molecules ${ }^{-1} \mathrm{~s}^{-1}$ and in the range of $10^{-19}-10^{-14} \mathrm{~cm}^{3}$ molecules ${ }^{-1} \mathrm{~s}^{-1}$ for $\mathrm{O}_{3}$ with monoterpenes 
(Atkinson, 1997; Calogirou et al., 1999; Martínez et al., 1999; Orlando et al., 2000; Oliveira and Bauerfeldt, 2012). Using the 12 -h daytime average $\mathrm{OH}$ radical concentration of $2 \times 10^{6}$ molecules cm${ }^{-3}$, 12-h nighttime average $\mathrm{NO}_{3}$ radical concentration of $2.5 \times 10^{8}$ molecules $\mathrm{cm}^{-3}$ and 24 -h average $\mathrm{O}_{3}$ concentration of $7 \times 10^{11}$ molecules $\mathrm{cm}^{-3}$, the fast monoterpene ozonolysis reaction can compete with the $\mathrm{OH}$ reaction during the day and the $\mathrm{NO}_{3}$ reaction at night. Therefore, ozonolysis serves as an important monoterpene loss pathway (Orlando et al., 2000; Atkinson and Arey, 2003; Qin et al., 2018). In addition, a large variety of low-volatility organic compounds, including carbonyl compounds (aldehydes and ketones), hydroxyl compounds and organic acids, have been identified in SOAs generated from the ozonolysis of monoterpenes, such as $\alpha$-pinene, $\beta$-pinene, $\alpha$-phellandrene, limonene, and sabinene (Jacksonet et al., 2016; Sato et al., 2016; Scorch et al., 2017). Therefore, SOAs formation by the oxidation of monoterpenes is mainly dominated by the ozonolysis reaction.

Monoterpenes generally contain 1-3 unsaturated $>\mathrm{C}=\mathrm{C}<$ double bonds and are highly reactive. The proposed reaction mechanism for monoterpene ozonolysis starts with $\mathrm{O}_{3}$ addition to $\mathrm{C}=\mathrm{C}$ double bonds, which lead to the formation of primary ozonide (POZ). The formed POZ will then rapidly decompose to form Criegee intermediates $(\mathrm{Cls})$. Chemically activated $\mathrm{Cls}$ may undergo unimolecular decomposition or isomerization, or bimolecular reactions with $\mathrm{H}_{2} \mathrm{O}$, $\mathrm{NO}$ and $\mathrm{SO}_{2}$ (Kleindienst et al., 2006; Jaoui et al., 2008; Lin et al., 2014; Jackson et al., 2017; Almatarneh et al., 2019), with many previous studies reporting the importance of bimolecular reactions for SOA formation.

Neeb et al. (1997) found that hydroxymethyl hydroperoxide (HMHP) was the sole product of the reaction between $\mathrm{CH}_{2} \mathrm{OO}$ and water $\mathrm{H}_{2} \mathrm{O}$. $\mathrm{HMHP}$ can then be rapidly decomposed into lowvolatility organic compounds such as methacrolein and methyl vinyl ketone (Sauer et al., 1999). Presto et al. (2005) reported SOA yields from the ozonolysis of $\alpha$-pinene in the presence of $\mathrm{NO}_{x}$, suggesting that $\mathrm{Cls}$ can react with $\mathrm{NO}$, typically resulting in carbonyl and organic nitrate functionality. Mauldin et al. (2012) found that the oxidation of $\mathrm{SO}_{2}$ to $\mathrm{H}_{2} \mathrm{SO}_{4}$ by Cls leads to an increase in the production of sulfate aerosols in boreal forests. Sipilä et al. (2014) also reported that the reaction between $\mathrm{SO}_{2}$ and $\mathrm{Cls}$ formed from monoterpene ozonolysis is an important source of atmospheric sulfate and SOAs. In addition, Ye et al. (2018) studied $\alpha$-pinene and limonene ozonolysis in the presence of $\mathrm{SO}_{2}$, finding that the reaction of $\mathrm{SO}_{2}$ with $\mathrm{Cls}$ was responsible for altering SOAs yields. Although these experimental studies indicated that bimolecular Cls reactions were related to SOAs formation, the chemical processes behind these interactions are not yet fully understood. Moreover, most theoretical studies have focused on small Cls, especially the simple carbonyl oxide $\mathrm{CH}_{2} \mathrm{OO}$ (Aplincourt and Ruiz-López, 2000; Vereecken et al., 2012; Nguyen et al., 2016). Therefore, it is necessary to study the specific mechanism of SOAs formation from large Cls formed from monoterpene ozonolysis.

As a natural acyclic monoterpene, citral is found in a wide variety of plants, such as Indian lemon grass species and Litsea cubeba, and can be used as a key ingredient for various chemical products (Rauber et al., 2005; Gil et al., 2007; Saddiq and Khayyat, 2010). Citral (3,7-dimethyl2,6-octadienal) is a mixture of two isomeric acyclic monoterpene aldehydes, neral and geranial (Fig. 1), caused by cis-trans isomerism at the $\mathrm{C}=\mathrm{C}$ bond near the aldehyde group. In this article, neral was used to theoretically explore the gas-phase ozonolysis of citral in the presence of $\mathrm{H}_{2} \mathrm{O}$, $\mathrm{NO}$ and $\mathrm{SO}_{2}$, providing novel insights on the formation mechanisms of SOAs during monoterpenes ozonolysis and further deepening our understanding of the atmospheric SOAs.

\section{COMPUTATIONAL METHODS}

All geometric optimizations were performed using the Gaussian 09 program (Frisch et al., 2009). And in each elementary reaction, the geometric parameters of reactants, pre-reactive complex (PRC), intermediates (IMs), transition states (TSs) and products, were optimized using the M06-2X functional with the $6-31+G(d, p)$ basis set. Zheng et al. (2009) calculated the barrier heights of DBH24/08 database using 348 model chemistries, including heavy-atom transfer (HATBH6), nucleophilic substitution (NSBH6), unimolecular and association (UABH6), and hydrogen-transfer $(\mathrm{HTBH} 6)$ reactions. The selected functional $M 06-2 \mathrm{X} / 6-31+\mathrm{G}(\mathrm{d}, \mathrm{p})$ was proven to be reliable and appropriate for the configuration optimization and thermodynamic calculation of ozonolysis 
<smiles>CC(C)=CCCC(C)=CC=O</smiles>

Neral (cis-Citral)<smiles>CC(C)=CCCC(C)=CC=O</smiles>

Geranial (trans-Citral)

Fig. 1. The structure of neral and geranial.

(Sun et al., 2018; Wang et al., 2019). At the same level of theory, frequency calculations were performed to obtain zero-point energy corrections. The transition states were identified by only one imaginary frequency. More accurate single energies could be obtained using a larger basis set of $6-311++G(3 d f, 3 p d)$.

Using the KiSThelP program (Truhlar et al., 1996; Canneaux et al., 2014), rate constants were calculated using transition-state theory (TST) with Wigner tunneling correction at a pressure of 1.0 bar and $298 \mathrm{~K}$. A scaling factor of 0.967 was applied to the frequency calculated at the M062X/6-31+G(d,p) level (Alecu et al., 2010).

When the reaction involved pre-reactive complexes, the reaction rate constants were calculated using the formula described in Eq. (1) (Shiroudi and Deleuze, 2014), as follows:

$R_{1}+R_{2} \stackrel{K_{e q}}{\longrightarrow} R_{1} \cdots R_{2} \stackrel{k_{1}}{\longrightarrow} I M$

where $K_{\text {eq }}$ represents the equilibrium constant for the first reaction step, R1...R2 means the prereactive complexes. The thermodynamic expression of the equilibrium constant for gas-phase reactions is employed in KiSThelP, as described in Eq. (2) as follows:

$K_{e q}=e^{-\frac{\Delta G^{0}(T)}{R T}}$

where $\Delta G^{0}(T)$ is the associated standard reaction Gibbs energy at temperature $T$ and $R$ is the ideal gas constant. Furthermore, the unimolecular reaction rate constant $\left(k_{1}\right)$ employed in KiSThelP is the thermodynamic equivalent of Eq. (3):

$k=\sigma \frac{k_{b} T}{h}\left(\frac{R T}{P^{0}}\right)^{\Delta n} e^{-\frac{\Delta G^{0, \neq}(T)}{k_{b} T}}$

where $\sigma$ is the reaction path degeneracy; $k_{\mathrm{b}}$ is Boltzmann's constant; $T$ is the temperature; $h$ is Planck's constant; $R$ is the ideal gas constant and $P^{0}=1$ bar, with the $R T / P^{0}$ unit being the inverse of a concentration; $\Delta n$ is 1 or 0 for gas-phase bimolecular or unimolecular reactions; and $\Delta G^{0, \neq}(T)$ represents the standard Gibbs free energy of activation for the reaction.

The overall rate constant can be calculated according to Eq. (4) as follows:

$k_{\text {overall }}=K_{\text {eq }} \cdot k_{1}$

\section{RESULTS AND DISCUSSIONS}

\subsection{The Formation and Decomposition of Primary Ozonides}

Atomic labels are marked in the structure of citral in Fig. 1. Fig. 2 depicts the detailed reaction 


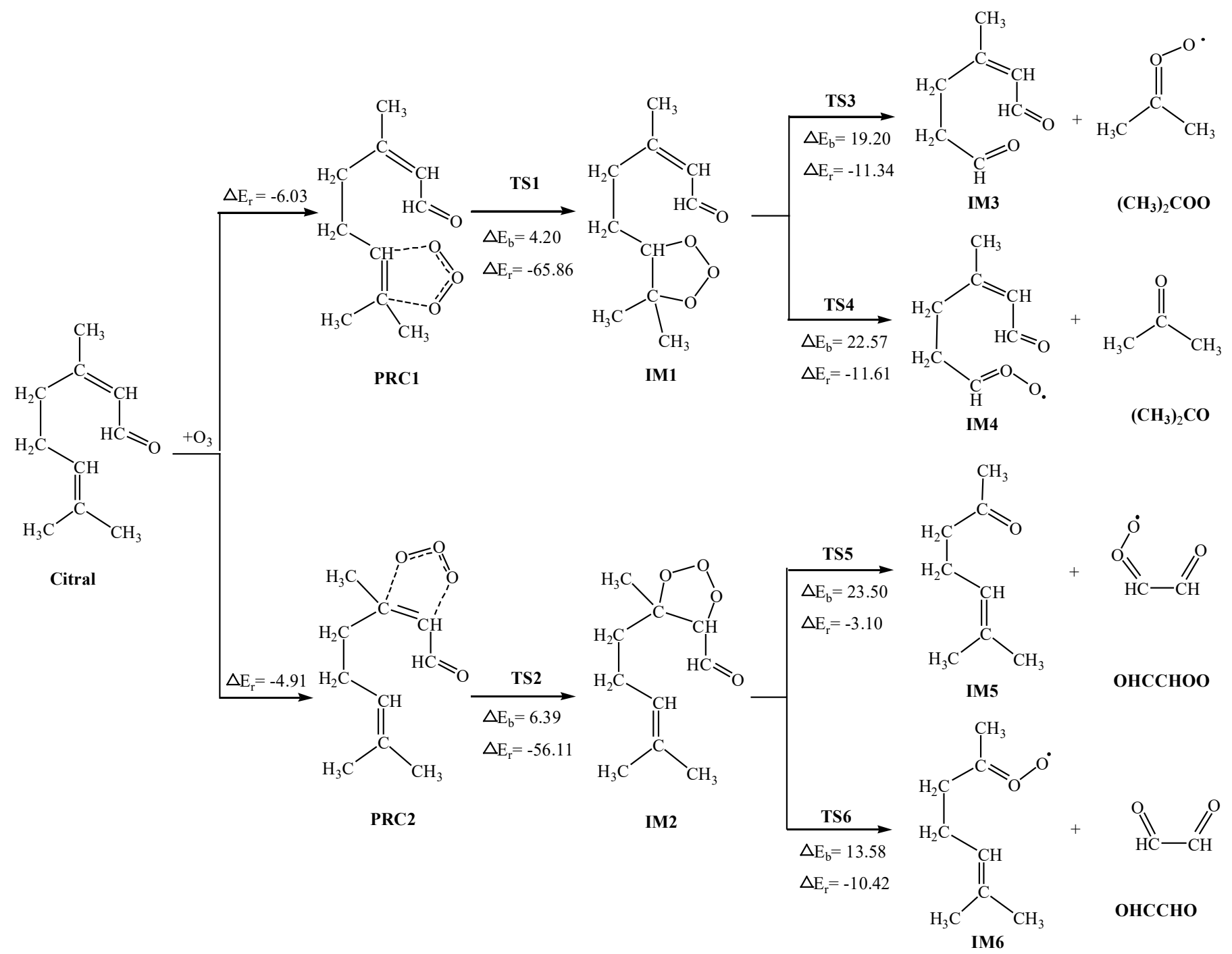

Fig. 2. The mechanisms for the formation and decomposition of primary ozonides at the M06-2X/6-311++G(3df,3pd)//M06$2 \mathrm{X} / 6-31+\mathrm{G}(\mathrm{d}, \mathrm{p})$ level of theory $\left(\mathrm{kcal} \mathrm{mol}^{-1}\right)$.

mechanism for the formation and decomposition of POZs, in which the potential barriers $\left(\Delta \mathrm{E}_{\mathrm{b}}\right)$ and reaction heats $\left(\Delta \mathrm{E}_{\mathrm{r}}\right)$ are also given. Evidently, the reaction of citral with $\mathrm{O}_{3}$ follows the Criegee mechanism, consisting of a three-step reaction: (1) formation of PRCs, (2) electrophilic addition forming 5-member-ring primary ozonides (POZs), and (3) decomposition of POZs.

The ozonolysis of citral initiates with the addition of two terminal $\mathrm{O}$ atoms of $\mathrm{O}_{3}$ to $\mathrm{C}_{2}=\mathrm{C}_{3}$ and $C_{7}=C_{8}$, obtaining two PRCs (PRC1 and PRC2), with the two reactions release $6.03 \mathrm{kcal} \mathrm{mol}^{-1}$ and $4.91 \mathrm{kcal} \mathrm{mol}^{-1}$ of heat, respectively. Then the POZs (IM1 and IM2) are formed through TS1 and TS2. The barrier heights of these two parallel processes are $4.20 \mathrm{kcal} \mathrm{mol}^{-1}$ and $6.39 \mathrm{kcal} \mathrm{mol}^{-1}$, and the exothermic heat is $65.86 \mathrm{kcal} \mathrm{mol}^{-1}$ and $56.11 \mathrm{kcal} \mathrm{mol}^{-1}$, respectively. Therefore, the reaction of $\mathrm{O}_{3}$ with citral occurs easily under conventional atmospheric conditions.

Energized POZs have a 5-membered ring, which decomposes promptly to form carbonyl compounds [IM3, $\left(\mathrm{CH}_{3}\right)_{2} \mathrm{CO}$, IM5 and $\mathrm{OHCCHO}$ ] and the corresponding $\mathrm{Cls}$ [IM4, $\left(\mathrm{CH}_{3}\right)_{2} \mathrm{COO} \cdot$, IM6 and $\mathrm{OHCCHOO} \cdot]$ through the cleavage of the $\mathrm{C}-\mathrm{C}$ bond and one of the $\mathrm{O}-\mathrm{O}$ bonds.

Table 1 lists the calculated rate coefficients $k$ of $\mathrm{O}_{3}$ with citral at $298 \mathrm{~K}$. The predicted rate coefficient of $\mathrm{O}_{3}$ with citral at $298 \mathrm{~K}$ was $6.97 \times 10^{-17} \mathrm{~cm}^{3}$ molecules ${ }^{-1} \mathrm{~s}^{-1}$, falling within the previously reported range of $10^{-19}-10^{-14} \mathrm{~cm}^{3}$ molecules ${ }^{-1} \mathrm{~s}^{-1}$. Additions to $C_{2}=C_{3}$ bond account for more than $99 \%$ of the branching ratio and thus, further analysis focuses on the fate after addition to $\mathrm{C}_{2}=\mathrm{C}_{3}$ bond only. 
Table 1. Calculated rate constants for the ozonolysis of citral and Criegee intermediate reactions.

\begin{tabular}{ll}
\hline Reactions & $k_{298 \mathrm{~K}}\left(\mathrm{~cm}^{3} \text { molecules }^{-1} \mathrm{~s}^{-1} \text { or s}^{-1}\right)^{\mathrm{a}}$ \\
\hline $\mathrm{Citral}+\mathrm{O}_{3} \rightarrow \mathrm{PRC} 1 \rightarrow \mathrm{IM} 1$ & $6.92 \times 10^{-17}$ \\
$\mathrm{Citral}+\mathrm{O}_{3} \rightarrow \mathrm{PRC2} \rightarrow \mathrm{IM} 2$ & $4.57 \times 10^{-20}$ \\
$\mathrm{IM} 4 \rightarrow \mathrm{DO}$ & $1.59 \times 10^{-3}$ \\
$\mathrm{IM} 4+\mathrm{H}_{2} \mathrm{O} \rightarrow \mathrm{HAHP}$ & $5.07 \times 10^{-16}$ \\
$\mathrm{IM} 4+\mathrm{NO} \rightarrow \mathrm{IM} 3+\mathrm{NO}_{2}$ & $1.58 \times 10^{-22}$ \\
$\mathrm{IM} 4+\mathrm{NO} \rightarrow \mathrm{IM} 1-\mathrm{NO}(2)$ & $6.70 \times 10^{-21}$ \\
$\mathrm{IM} 4+\mathrm{SO}_{2} \rightarrow \mathrm{PRC}-\mathrm{SO}_{2} \rightarrow \mathrm{IM} 1-\mathrm{SO}_{2}$ & $3.19 \times 10^{-10}$ \\
$\mathrm{IM} 3+\mathrm{O}_{3} \rightarrow \mathrm{PRC} 3 \rightarrow \mathrm{IM} 8$ & $8.61 \times 10^{-19}$ \\
\hline
\end{tabular}

${ }^{\mathrm{a}} \mathrm{s}^{-1}$ for unimolecular reaction, $\mathrm{cm}^{3}$ molecules ${ }^{-1} \mathrm{~s}^{-1}$ for bimolecular reactions.

\subsection{Criegee Intermediate Reactions}

The addition of $\mathrm{O}_{3}$ to the $\mathrm{C}_{2}=\mathrm{C}_{3}$ bond will be decomposed into two $\mathrm{Cls},\left(\mathrm{CH}_{3}\right)_{2} \mathrm{COO} \cdot$ and IM4. The reactions of $\left(\mathrm{CH}_{3}\right)_{2} \mathrm{COO}$. have been widely investigated in recent studies (Vereecken et al., 2012; Chhantyal-Pun et al., 2017; Deng et al., 2018). In the atmosphere, the stabilized $\left(\mathrm{CH}_{3}\right)_{2} \mathrm{COO}$. can undergo unimolecular isomerization reaction to form $\mathrm{CH}_{2}=\mathrm{C}\left(\mathrm{CH}_{3}\right) \mathrm{OOH}$, and can also react with $\mathrm{SO}_{2}, \mathrm{NO}_{2}$, and $\mathrm{H}_{2} \mathrm{O}$ (Deng et al., 2018). The present study focused on the fate of IM4, which may also undergo unimolecular reactions, or bimolecular reactions with water vapor and other trace gases, e.g., $\mathrm{H}_{2} \mathrm{O}, \mathrm{SO}_{2}$ and $\mathrm{NO}_{2}$. Fig. 3 shows the profile of the potential energy surface for the reaction of IM4. The single molecular degradation of large $\mathrm{Cls}$ includes the hydrogen-shift reaction, the bicyclic ring closure reactions and ring cyclization to form dioxirane (DO; Long et al., 2019). Instead of intramolecular hydrogen migration and the bicyclic ring closure reactions, IM4 can undergo ring cyclization to form DO via an exothermic process and with a reaction barrier of about $22.20 \mathrm{kcal} \mathrm{mol}^{-1}$. The rate coefficients at $298 \mathrm{~K}$ were estimated as $1.59 \times 10^{-3} \mathrm{~s}^{-1}$.

\subsubsection{Reaction with $\mathrm{H}_{2} \mathrm{O}$}

In atmospheric chemistry, one of the most important reactions is considered to be the reaction with $\mathrm{H}_{2} \mathrm{O}$ because of its high abundance. Previous theoretical and experimental studies have shown that the reaction between $\mathrm{Cls}$ and $\mathrm{H}_{2} \mathrm{O}$ occurs via three main reaction channels (Qi and Chao, 2007; Wang et al., 2019). The pathway to produce organic peroxides is likely to be thermodynamically and kinetically advantageous compared with the other two pathways. In this channel, the $\mathrm{H}-\mathrm{O}$ bond in $\mathrm{H}_{2} \mathrm{O}$ is broken to generate $\mathrm{OH}$ group and $\mathrm{H}$ atom. The obtained $\mathrm{OH}$ group is attached to the $\mathrm{C}$ atom, while the $\mathrm{H}$ atom is simultaneously combined with $\mathrm{COO}$. to form hydroxyalkyl hydroperoxides (HAHP). This process crosses a small potential barrier of $3.31 \mathrm{kcal} \mathrm{mol}^{-1}$ and is highly exothermic, generating $43.43 \mathrm{kcal} \mathrm{mol}^{-1}$ of energy.

For reaction with water, the rate coefficient at $298 \mathrm{~K}$ was estimated as $5.07 \times 10^{-16}$ $\mathrm{cm}^{3}$ molecules ${ }^{-1} \mathrm{~s}^{-1}$ based on the TST, which is similar to the rate coefficient of $2.46 \times 10^{-16}$ $\mathrm{cm}^{3}$ molecules ${ }^{-1} \mathrm{~s}^{-1}$ for $\mathrm{CH}_{3} \mathrm{CHOO}$ (Wang and Wang, 2017). Theoretical studies have also shown that the reaction between $\left(\mathrm{CH}_{3}\right)_{2} \mathrm{COO}$ and water monomer is slow, and the rate coefficients at $298 \mathrm{~K}$ is $2.4 \times 10^{-17} \mathrm{~cm}^{3}$ molecules ${ }^{-1} \mathrm{~s}^{-1}$ (Anglada and Sole, 2016).

When the relative humidity $(\mathrm{RH})$ is $50 \%$, the concentration of water vapor is about $3.8 \times 10^{17}$ molecules $\mathrm{cm}^{-3}$. Then the effective bimolecular rate is $193 \mathrm{~s}^{-1}$, which is much higher than the unimolecular rate of $1.59 \times 10^{-3} \mathrm{~s}^{-1}$.

\subsubsection{Reaction with NO}

In the presence of $\mathrm{NO}_{x}$, Cls can react with $\mathrm{NO}$ radicals, resulting in the formation of carbonyl and organic nitrate functionality. Two reaction pathways were established for the reaction between $\mathrm{Cls}$ and $\mathrm{NO}$. The first is the formation of a 5-membered ring adduct with a nitrogen-centered radical, with a reaction barrier calculated at $9.12 \mathrm{kcal} \mathrm{mol}^{-1}$; then step by step the $\mathrm{C}-\mathrm{O}$ bond and $\mathrm{O}-\mathrm{O}$ bond will break, resulting in the formation of carbonyl compounds and $\mathrm{NO}_{2}$. The other pathway involves $\mathrm{NO}$ extraction of the terminal oxygen of $\mathrm{Cl}$, which directly generates carbonyl compounds and $\mathrm{NO}_{2}$. The reaction barrier for this pathway is slightly higher than that of cycloaddition, at $13.58 \mathrm{kcal} \mathrm{mol}^{-1}$. 


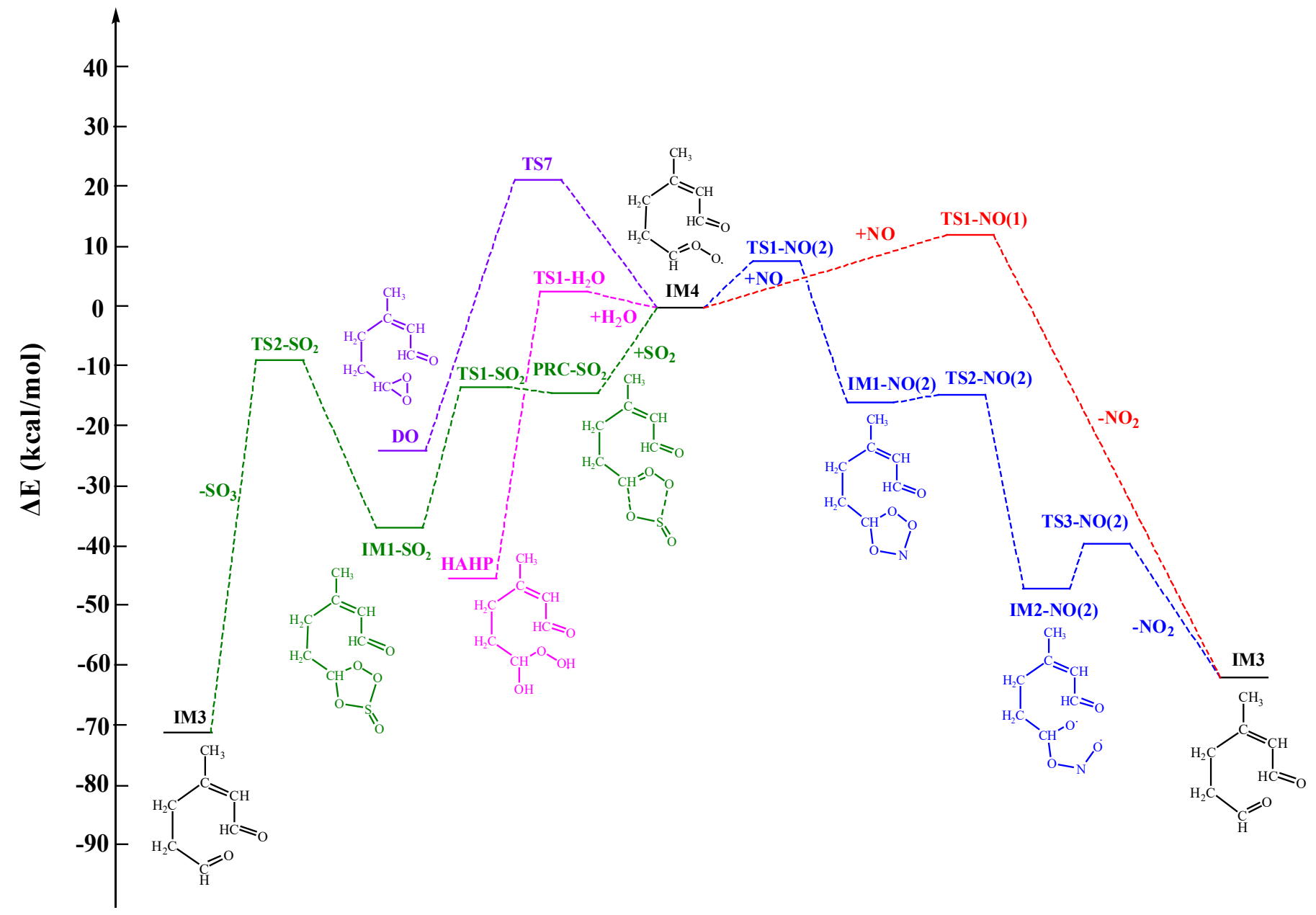

Fig. 3. The profile of the potential energy surface for the reaction of Criegee intermediates at the M06-2X/6-311++G(3df,3pd)//M06$2 \mathrm{X} / 6-31+\mathrm{G}(\mathrm{d}, \mathrm{p})$ level of theory $\left(\mathrm{kcal} \mathrm{mol}^{-1}\right)$.

Overall, it may be concluded that the reaction between $\mathrm{Cl}$ and $\mathrm{NO}$ yields a carbonyl compound and $\mathrm{NO}_{2}$, proceeding mostly through the formation of a cyclic intermediate. The NO reaction may act as a route for oxidizing $\mathrm{NO}$ to $\mathrm{NO}_{2}$ in the atmosphere, affecting $\mathrm{NO} / \mathrm{NO}_{2}$ conversion rates. The associated $\mathrm{NO}^{-\mathrm{NO}_{2}}$ cycling is particularly important for the production of tropospheric $\mathrm{O}_{3}$ (Murray et al., 2013; Newsome and Evans, 2017; Ridley et al., 2017). $\mathrm{O}_{3}$ is produced by the photolysis of $\mathrm{NO}_{2}$ during the day, and reacts irreversibly with $\mathrm{NO}$ to form $\mathrm{NO}_{2}$ at night. But the presence of $\mathrm{Cls}$ may compete with $\mathrm{O}_{3}$ and reduce the reaction between $\mathrm{NO}$ and $\mathrm{O}_{3}$ at night, leading to the accumulation of $\mathrm{O}_{3}$.

The overall rate coefficient of IM4 with NO was estimated as $6.85 \times 10^{-21} \mathrm{~cm}^{3}$ molecules ${ }^{-1} \mathrm{~s}^{-1}$ at $298 \mathrm{~K}$, which is $\mathbf{2}-3$ orders of magnitude lower than the estimated rate coefficient (Vereecken et al., 2012). The concentrations of NO in forests, rural areas and cities are 3.3-4.8 $\times 10^{8}, 1.1 \times$ $10^{10}$ and $9 \times 10^{10}$ molecules $\mathrm{cm}^{-3}$, respectively. Thus, the effective bimolecular rate of IM4 with NO is $2.26 \times 10^{-12}-6.17 \times 10^{-10} \mathrm{~s}^{-1}$.

\subsubsection{Reaction with $\mathrm{SO}_{2}$}

In the atmosphere, the Criegee intermediate IM4 can also undergo bimolecular reactions with $\mathrm{SO}_{2}$, which begins with the formation of a pre-reactive complex $\left(\mathrm{PRC}-\mathrm{SO}_{2}\right)$. This process releases $13.57 \mathrm{kcal} \mathrm{mol}^{-1}$ of energy. Then the 5 -membered ring adduct IM1-SO $\mathrm{SO}_{2}$ is obtained via $\mathrm{TS}_{1}-\mathrm{SO}_{2}$, with this process being constrained by a reaction barrier height of $1.02 \mathrm{kcal} \mathrm{mol}^{-1}$ and being exothermic by $23.67 \mathrm{kcal} \mathrm{mol}^{-1}$. Finally, the 5-membered ring intermediate breaks the $0-0$ and $\mathrm{C}-\mathrm{O}$ bonds to form a carbonyl compound (IM3) and $\mathrm{SO}_{3} . \mathrm{SO}_{3}$ condenses with water to form fine sulfate aerosol particles in the atmosphere, which not only affects global climate change, but also 
harms human health (Sarwar et al., 2013). This pathway can also account for non-OH sources in the atmosphere leading to increased sulfate aerosol production in coastal (Berresheim et al., 2014) and boreal forest environments (Mauldin et al., 2012).

The overall rate coefficient $k$ of $\mathrm{SO}_{2}$ with IM4 is $3.19 \times 10^{-10} \mathrm{~cm}^{3}$ molecules ${ }^{-1} \mathrm{~s}^{-1}$ at ambient temperature and 760 Torr, which is close to the previously reported experimental values of 2.4$6.7 \times 10^{-11} \mathrm{~cm}^{3}$ molecules ${ }^{-1} \mathrm{~s}^{-1}$ for $\mathrm{CH}_{3} \mathrm{CHOO}$ (Taatjes et al., 2013), $1.3 \times 10^{-11} \mathrm{~cm}^{3}$ molecules $^{-1} \mathrm{~s}^{-1}$ for $\left(\mathrm{CH}_{3}\right)_{2} \mathrm{COO}$ (Huang et al., 2015), and $(4.2 \pm 0.6) \times 10^{-11} \mathrm{~cm}^{3}$ molecules ${ }^{-1} \mathrm{~s}^{-1}$ for methyl vinyl ketone oxide (Caravan et al., 2020), as well as the theoretical values of $(3.68 \pm 0.02) \times 10^{-11} \mathrm{~cm}^{3}$ molecules ${ }^{-1} \mathrm{~s}^{-1}$ for $\mathrm{CH}_{2} \mathrm{OO}$ (Kuwata et al., 2015) and 5.27-6.54 $\times 10^{-10} \mathrm{~cm}^{3}$ molecules ${ }^{-1} \mathrm{~s}^{-1}$ for My$\mathrm{Cls}$ (Deng et al., 2018). The concentration ranges of $\mathrm{SO}_{2}$ is about $1.7 \times 10^{10}$ molecules $\mathrm{cm}^{-3}$ in the boreal forest, $9 \times 10^{10}$ molecules $\mathrm{cm}^{-3}$ in a megacity and $6.6 \times 10^{9}$ molecules $\mathrm{cm}^{-3}$ in rural Europe (Vereecken et al., 2012); thus the effective bimolecular rate of IM4 with respect to the reaction with $\mathrm{SO}_{2}$ is about $2.11-28.71 \mathrm{~s}^{-1}$. If $\mathrm{SO}_{2}$ is present in the atmosphere at a typical level of $5 \times 10^{11}$ molecules $\mathrm{cm}^{-3}$ ( $20 \mathrm{ppbv}$ ) (Deng et al., 2018), the effective bimolecular rate of IM4 with respect to the reaction with $\mathrm{SO}_{2}$ is $159.5 \mathrm{~s}^{-1}$.

\subsection{Fate of IM3}

As shown in Fig. 4, the carbonyl compound IM3 can further react with $\mathrm{O}_{3}$, with ozone approaching the $>\mathrm{C}=\mathrm{C}<$ bond forming a 5-member-ring IM8 compound via pre-reactant complexes (PRC3). This process contains a total excess energy of approximately $68.52 \mathrm{kcal} \mathrm{mol}^{-1}$, which is sufficient to cause rapid ring breakage. The primary product channels were identified as IM9 $\left(\mathrm{CH}_{3} \mathrm{COCH}_{2} \mathrm{CH}_{2} \mathrm{CHOO} \cdot\right)+$ trans-glyoxal $(\mathrm{OHCCHO})$ or levulinic aldehyde $\left(\mathrm{CH}_{3} \mathrm{COCH}_{2} \mathrm{CH}_{2} \mathrm{CHO}\right)+$ $\mathrm{Cls}$ (OHCCHOO-), with potential barriers of 16.63 and $24.76 \mathrm{kcal} \mathrm{mol}^{-1}$, respectively. The Cls $\mathrm{OHCCHOO}$. and $\mathrm{CH}_{3} \mathrm{COCH}_{2} \mathrm{CH}_{2} \mathrm{CHOO}$. can further react with $\mathrm{H}_{2} \mathrm{O}, \mathrm{SO}_{2}$ and $\mathrm{NO}$ to form the stabilized products glyoxal and levulinic aldehyde, respectively.

\section{CONCLUSIONS}

We applied quantum chemistry and kinetic calculations to identify the mechanism driving the ozonolysis of citral and gained the following insights:

1) POZs can be formed by the attachment of $\mathrm{O}_{3}$ to $\mathrm{C}=\mathrm{C}$, after which carbonyl molecules and $\mathrm{Cls}$ can be formed by the simultaneous cleavage of the $\mathrm{C}-\mathrm{C}$ bond of the forming 5-member-ring and one of the O-O bonds.

2) Cls can isomerize at a rate of $1.59 \times 10^{-3} \mathrm{~s}^{-1}$. Additionally, they can bimolecularly react with $\mathrm{H}_{2} \mathrm{O}$ and $\mathrm{SO}_{2}$ at rates of $193 \mathrm{~s}^{-1}$ and $159.5 \mathrm{~s}^{-1}$, respectively, and, to a far lesser degree, with $\mathrm{NO}$ (at a rate of $2.26 \times 10^{-12}$ to $6.17 \times 10^{-10} \mathrm{~s}^{-1}$ ). More importantly, Cls can oxidize $\mathrm{SO}_{2}$ into $\mathrm{SO}_{3}$, leading to the production of sulfuric acid.

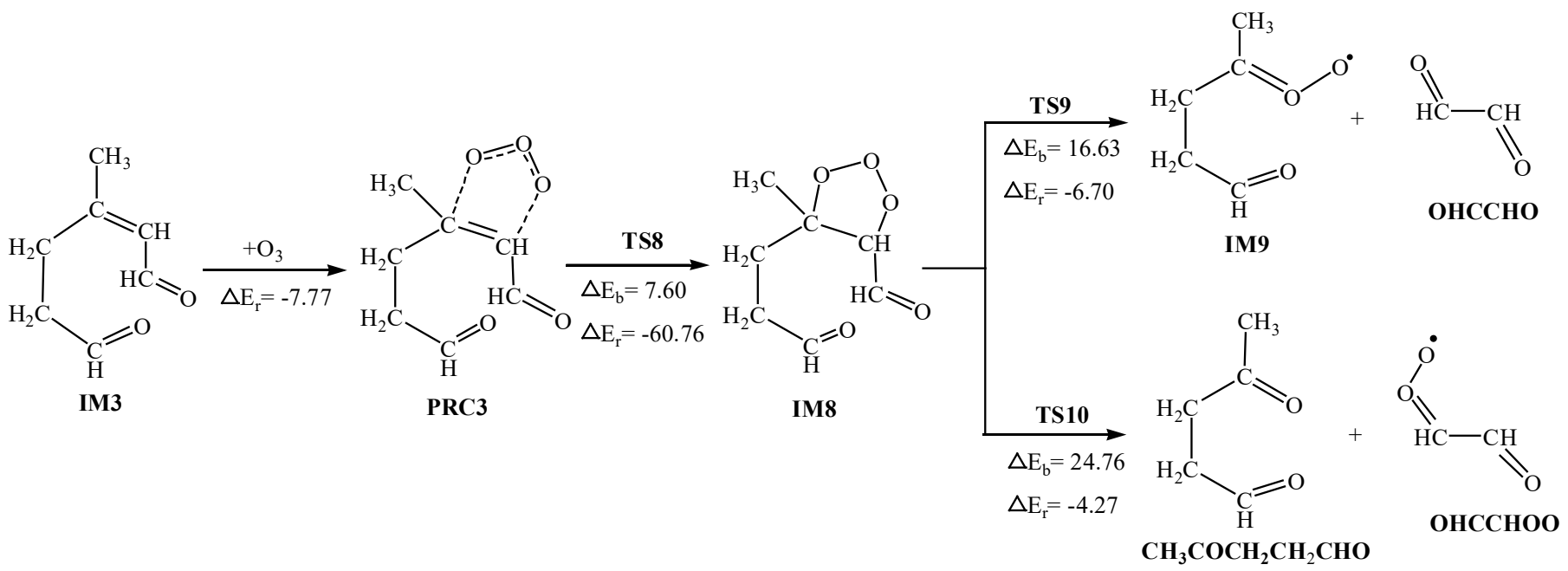

Fig. 4. The fate of $I M 3$ with $\mathrm{O}_{3}$ at the $M 06-2 X / 6-311++G(3 d f, 3 p d) / / M 06-2 X / 6-31+G(d, p)$ level of theory $\left(\mathrm{kcal}^{\mathrm{mol}}{ }^{-1}\right)$. 
The ozonolysis of citral potentially produces low-volatility species with increased water solubility, such as aldehydes $[-\mathrm{C}(=\mathrm{O}) \mathrm{H}]$, ketones $[-\mathrm{C}(=\mathrm{O})-]$, alcohols $(-\mathrm{OH})$, and hydroperoxides $(-\mathrm{OOH})$, which can form SOA through the nucleation, condensation, and/or partitioning of the condensed and gaseous phases.

\section{ACKNOWLEDGEMENTS}

This work is supported by National Natural Science Foundation of China (21607011, 21976109), Key Research and Development Project of Shandong Province (2019GSF109021, 2019GSF109037), and Natural Science Foundation of Shandong Province (ZR2018MB043).

\section{SUPPLEMENTARY MATERIAL}

Supplementary data associated with this article can be found in the online version at https://doi.org/10.4209/aaqr.200637

\section{REFERENCE}

Alecu, I.M., Zheng, J., Zhao, Y., Truhlar, D.G. (2010). Computational thermochemistry: Scale factor databases and scale factors for vibrational frequencies obtained from electronic model chemistries. J. Chem. Theory Comput. 6, 2872-2887. https://doi.org/10.1021/ct100326h

Almatarneh, M.H., Elayan, I.A., Altarawneh, M., Hollett J.W. (2019). A computational study of the ozonolysis of sabinene. Theor. Chem. Acc. 138, 30. https://doi.org/10.1007/s00214-019-2420-7

Anglada, J.M., Sole, A. (2016). Impact of the water dimer on the atmospheric reactivity of carbonyl oxides. Phys. Chem. Chem. Phys. 18, 17698-17712. https://doi.org/10.1039/C6CP02531E

Aplincourt, P., Ruiz-López, M.F. (2000). Theoretical investigation of reaction mechanisms for carboxylic acid formation in the atmosphere. J. Am. Chem. Soc. 122, 8990-8989. https://doi.org/10.1021/ja000731z

Atkinson, R. (1997). Gas-phase tropospheric chemistry of volatile organic compounds: 1. Alkanes and Alkenes. J. Phys. Chem. Ref. Data 26, 215-290. https://doi.org/10.1063/1.556012

Atkinson, R., Arey, J. (2003). Gas-phase tropospheric chemistry of biogenic volatile organic compounds: A review. Atmos. Environ. 37, S197-S219. https://doi.org/10.1016/S1352-2310/0 3)00391-1

Berresheim, H., Adam, M., Monahan, C., O'Dowd, C.D., Plane, J.M.C., Bohn, B., Rohrer, F. (2014). Missing $\mathrm{SO}_{2}$ oxidant in the coastal atmosphere? - observations from high-resolution measurements of $\mathrm{OH}$ and atmospheric sulfur compounds. Atmos. Chem. Phys. 14, 1220912223. https://doi.org/10.5194/acp-14-12209-2014

Boy, M., Mogensen, D., Smolander, S., Zhou, L., Nieminen, T., Paasonen, P., Plass-Dulmer, C., Sipila, M., Petaja, T., Mauldin, L., Berresheim, H., Kulmala, M. (2013). Oxidation of $\mathrm{SO}_{2}$ by stabilized Criegee intermediate $(\mathrm{sCl})$ radicals as a crucial source for atmospheric sulfuric acid concentrations. Atmos. Chem. Phys. 13, 3865-3879. https://doi.org/10.5194/acp-13-3865-2013

Calogirou, A., Larsen, B.R., Kotzias, D. (1999). Gas-phase terpene oxidation products: A review. Atmos. Environ. 33, 1423-1439. https://doi.org/10.1016/S1352-2310(98)00277-5

Canneaux, S., Bohr, F., Henon, E. (2014). KiSThelP: A program to predict thermodynamic properties and rate constants from quantum chemistry results. J. Comput. Chem. 35, 82-93. https://doi.org/10.1002/jcc.23470

Caravan, R.L., Vansco, M.F., Au, K., Khan, M.A.H., Li, Y.L., Winiberg, F.A.F., Zuraski, K., Lin, Y.H., Chao, W., Trongsiriwat, N., Walsh, P.J., Osborn, D.L., Percival, C.J., Lin, J.M., Shallcross, D.E., Sheps, L., Klippenstein, S.J., Taatjes, C.A., Lester, M.I. (2020). Direct kinetic measurements and theoretical predictions of an isoprene-derived Criegee intermediate. Proc. Natl. Acad. Sci. U.S.A. 117, 9733-9740. https://doi.org/10.1073/pnas.1916711117

Chhantyal-Pun, R., Welz, O., Savee, J.D., Eskola, A.J., Taatjes, C.A. (2016). Direct measurements of unimolecular and bimolecular reaction kinetics of the Criegee intermediate $\left(\mathrm{CH}_{3}\right)_{2} \mathrm{COO}$. J. Phys. Chem. A 121, 4-15. https://doi.org/10.1021/acs.jpca.6b07810 
Deng, P., Wang, L.Y., Wang, L.M. (2018). Mechanism of gas-phase ozonolysis of $\beta$-Myrcene in the atmosphere. J. Phys. Chem. A 122, 3013-3020. https://doi.org/10.1021/acs.jpca.8b00983

Friedman, B., Farmer, D.K. (2018). SOA and gas phase organic acid yields from the sequential photooxidation of seven monoterpenes. Atmos. Environ. 187, 335-345. https://doi.org/10.10 16/j.atmosenv.2018.06.003

Frisch, M.J., Trucks, G.W., Schlegel, H.B., Scuseria, G.E., Robb, M.A., Cheeseman, J.R., Scalmani, G., Barone, V., Mennucci, B., Petersson, G.A., Nakatsuji, H., Caricato, M., Li, X., Hratchian, H.P., Izmaylov, A.F., Bloino, J., Zheng, G., Sonnenberg, J.L., Hada, M., ..., Fox, D.J. (2009). Gaussian 09. Revision B.01, Wallingford CT.

Gil, A., van Baren, C.M., Di Leo Lira, P., Bandoni, A.L. (2007). Identification of the genotype from contents and composition of the essential oil of lemon verbena (Aloysia citriodora Palau). J. Agric. Food Chem. 55, 8664-8669. https://doi.org/10.1021/jf0708387

Goldstein, A.H., Galbally, I.E. (2007). Known and unexplored organic constituents in the earth's atmosphere. Environ. Sci. Technol. 41, 1514-1521. https://doi.org/10.1021/es072476p

Guenther, A., Hewitt, C.N., Erickson, D., Fall, R., Geron, C., Graedel, T., Harley, P., Klinger, L., Lerdau, M., Mckay, W. A., Pierce, T., Scholes, B., Steinbrecher, R., Tallamraju, R., Taylor, J., Zimmerman, P. (1995). A global-model of natural volatile organic compound emissions. J. Geophys. Res. 100, 8873-8892. https://doi.org/10.1029/94JD02950

Hallquist, M., Wenger, J., Baltensperger, U., Rudich, Y., Simpson, D., Claeys, M., Dommen, J., Donahue, N., George, C., Goldstein, A.H., Hamilton, J.F., Herrmann, H., Hoffmann, T., linuma, Y., Jang, M., Jenkin, M.E., Jimenez, J.L., Kiendler-Scharr, A., Maenhaut, W., ..., Wildt, J. (2009). The formation, properties and impact of secondary organic aerosol: Current and emerging issues. Atmos. Chem. Phys. 9, 5155-5236. https://doi.org/10.5194/acpd-9-3555-2009

Huang, H.L., Chao, W., Lin, J.J.M. (2015). Kinetics of a Criegee intermediate that would survive high humidity and may oxidize atmospheric $\mathrm{SO}_{2}$. Proc. Natl. Acad. Sci. U.S.A. 112, 10857-10862. https://doi.org/10.1073/pnas.1513149112

Jackson, S.R., Ham, J.E., Harrison, J.C., Wells, J.R. (2016). Identification and quantification of carbonyl-containing $\alpha$-pinene ozonolysis products using O-tert-butylhydroxylamine hydrochloride. J. Atmos. Chem. 74, 325-338. https://doi.org/10.1007/s10874-016-9344-6

Jackson, S.R., Harrison, J.C., Ham, J.E., Wells, J.R. (2017). A chamber study of alkyl nitrate production formed by terpene ozonolysis in the presence of $\mathrm{NO}$ and alkanes. Atmos. Environ. 171, 143-148. https://doi.org/10.1016/j.atmosenv.2017.10.002

Jaoui, M., Edney, E.O., Kleindienst, T.E., Lewandowski, M., Offenberg, J.H., Surratt, J.D., Seinfeld, J.H. (2008). Formation of secondary organic aerosol from irradiated -pinene/toluene/ $\mathrm{NO}_{\mathrm{x}}$ mixtures and the effect of isoprene and sulfur dioxide. J. Geophys. Res. 113, D09303. https://doi.org/ 10.1029/2007jd009426

Jimenez, J.L., Canagaratna, M.R., Donahue, N.M., Prevot, A.S.H., Zhang, Q., Kroll, J.H., DeCarlo, P.F., Allan, J.D., Coe, H., Ng, N.L., Aiken, A.C., Docherty, K.S., Ulbrich, I.M., Grieshop, A.P., Robinson, A.L., Duplissy, J., Smith, J.D., Wilson, K.R., Lanz, V.A., ..., Worsnop, D. (2009). Evolution of organic aerosols in the atmosphere. Science 326, 1525-1529. https://doi.org/10.1 126/science.1180353

Kleindienst, T.E., Edney, E.O., Lewandowski, M., Offenberg, J.H., Jaoui, M. (2006). Secondary organic carbon and aerosol yields from the irradiations of isoprene and $\alpha$-pinene in the presence of $\mathrm{NO}_{x}$ and $\mathrm{SO}_{2}$. Environ. Sci. Technol. 40, 3807-3812. https://doi.org/10.1021/es052446r

Kuwata, K.T., Guinn, E.J., Hermes, M.R., Fernandez, J.A., Mathison, J.M., Huang, K. (2015). A computational re-examination of the Criegee intermediate-sulfur dioxide reaction. J. Phys. Chem. A 119, 10316-10335. https://doi.org/10.1021/acs.jpca.5b06565

Lin, X.X., Liu, Y.R., Huang, T., Xu, K.M., Zhang, Y., Jiang, S., Gai, Y.B., Zhang, W.J., Huang, W. (2014). Theoretical studies of the hydration reactions of stabilized Criegee intermediates from the ozonolysis of $\beta$-pinene. RSC Adv. 4, 28490-28498. https://doi.org/10.1039/c4ra04172k

Long, B., Bao, J.L., Truhlar, D.G. (2019). Rapid unimolecular reaction of stabilized Criegee intermediates and implications for atmospheric chemistry. Nat. Commun. 10, 2003. https://doi.org/10.1038/s41467-019-09948-7

Martínez, E., Cabañas, B., Aranda, A. Martín, P., Salgado, S. (1999). Absolute rate coefficients for the gas-phase reactions of $\mathrm{NO}_{3}$ radical with a series of monoterpenes at $\mathrm{T}=298$ to $433 \mathrm{~K}$. J. Atmos. Chem. 33, 265-282. https://doi.org/10.1023/A:1006178530211 
Mauldin, R.L., Berndt, T., Sipilä, M., Paasonen, P., Petäjä, T., Kim, S., Kurtén, T., Stratmann, F., Kerminen, V.M., Kulmala, M. (2012). A new atmospherically relevant oxidant of sulphur dioxide. Nature 488, 193-196. https://doi.org/10.1038/nature11278

Messina, P., Lathière, J., Sindelarova, K., Vuichard, N., Granier, C., Ghattas, J., Cozic, A., Hauglustaine, D.A. (2016). Global biogenic volatile organic compound emissions in the ORCHIDEE and MEGAN models and sensitivity to key parameters. Atmos. Chem. Phys. 16, 14169-14202. https://doi.org/10.5194/acp-16-14169-2016

Murray, L.T., Logan, J.A., Jacob, D.J. (2013). Interannual variability in tropical tropospheric ozone and $\mathrm{OH}$ : The role of lightning. J. Geophys. Res. 118, 11468-11480. https://doi.org/10.1002/jgr d. 50857

Nagori, J., Janssen, R.H.H., Fry, J.L., Krol, M., Jimenez, J.L., Hu, W., Vilà-Guerau de Arellano, J. (2019). Biogenic emissions and land-atmosphere interactions as drivers of the daytime evolution of secondary organic aerosol in the southeastern US. Atmos. Chem. Phys. 19, 701729. https://doi.org/10.5194/acp-19-701-2019

Neeb, P., Sauer, F., Horie, O., Moortgat, G.K. (1997). Formation of hydroxymethyl hydroperoxide and formic acid in alkene ozonolysis in the presence of water vapour. Atmos. Environ. 31, 1417-1423. https://doi.org/10.1016/S1352-2310(96)00322-6

Newsome, B., Evans, M. (2017). Impact of uncertainties in inorganic chemical rate constants on tropospheric composition and ozone radiative forcing. Atmos. Chem. Phys. 17, 14333-14352. https://doi.org/10.5194/acp-2017-12

Nguyen, T.B., Tyndall, G.S., Crounse, J.D., Teng, A.P., Bates, K.H., Schwantes, R.H., Coggon, M.M., Zhang, L., Feiner, P., Milller, D.O., Skog, K.M., Rivera-Rios, J.C., Dorris, M., Olson, K.F., Koss, A., Wild, R.J., Brown, S.S., Goldstein, A.H., de Gouw, J.A., ..., Wennberg, P.O. (2016). Atmospheric fates of Criegee intermediates in the ozonolysis of isoprene. Phys. Chem. Chem. Phys. 18, 10241-10254. https://doi.org/10.1039/c6cp00053c

Oberdorster, G., Oberdorster, E., Oberdorster, J. (2005). Nanotoxicology: Anemerging discipline evolving from studies of ultrafine particles. Environ. Health Perspect. 113, 823-839. https://doi.org/10.1289/ehp.7339

Oliveira, R.C.D.M., Bauerfeldt, G.F. (2012). Thermochemical analysis and kinetics aspects for a chemical model for camphene ozonolysis. J. Chem. Phys. 137, 134306. https://doi.org/10.1063/1.4757150

Orlando, J.J., Barbara Nozière, Tyndall, G.S., Orzechowska, G.E., Paulson, S.E., Rudich, Y. (2000). Product studies of the $\mathrm{OH}$ - and ozone-initiated oxidation of some monoterpenes. J. Geophys. Res. 105, 11561-11572. https://doi.org/10.1029/2000JD900005

Pope, C.A. III, Dockery, D.W. (2006). Health effects of fine particulate air pollution: Lines that connect. J. Air Waste Manage. Assoc. 56, 709-742. https://doi.org/10.1080/10473289.2006.1 0464545

Presto, A.A., Huff Hartz, K. E., Donahue, N.M. (2005). Secondary organic aerosol production from terpene ozonolysis. 2. Effect of $\mathrm{NO}_{x}$ concentration. Environ. Sci. Technol. 39, 7046-7054. https://doi.org/10.1021/es050174m

Qi, B., Chao, Y.T. (2007). Theoretical study on the mechanism and kinetics of the reaction of Criegee radical $\mathrm{CH}_{2} \mathrm{O}_{2}$ with $\mathrm{H}_{2} \mathrm{O}$. Acta Chim. Sinica 65, 2117-2123.

Qin, M.M., Hu, Y.T., Wang, X.S., Vasilakos, P., Boyd, C.M., Xu, L., Song, Y., Ng, N.L., Nenes, A., Russell, A.G. (2018). Modeling biogenic secondary organic aerosol (BSOA) formation from monoterpene reactions with $\mathrm{NO}_{3}$ : A case study of the SOAS campaign using CMAQ. Atmos. Environ. 184, 146-155. https://doi.org/10.1016/j.atmosenv.2018.03.042

Rauber, C.S., Guterres, S.S., Schapoval, E.E.S. (2005). LC determination of citral in Cymbopogon citratus volatile oil. J. Pharm. Biomed. Anal. 37, 597-601. https://doi.org/10.1016/j.jpba.2004. 10.042

Ridley, D., Cain, M., Methven, J., Arnold, S. (2017). Sensitivity of tropospheric ozone to chemical kinetic uncertainties in air masses influenced by anthropogenic and biomass burning emissions. Geophys. Res. Lett. 44, 7472-7481. https://doi.org/10.1002/2017GL073802

Saddiq, A.A., Khayyat, S.A. (2010). Chemical and antimicrobial studies of monoterpene: Citral. Pestic. Biochem. Phys. 98, 89-93. https://doi.org/10.1016/j.pestbp.2010.05.004

Sarwar, G., Fahey, K., Kwok, R., Gilliam, R.C., Roselle, S.J., Mathur, R., Xue, J., Yu, J.Z., Carter, W.P.L. (2013). Potential impacts of two $\mathrm{SO}_{2}$ oxidation pathways on regional sulfate concentrations: 
Aqueous-phase oxidation by $\mathrm{NO}_{2}$ and gas-phase oxidation by Stabilized Criegee Intermediates. Atmos. Environ. 68, 186-197. https://doi.org/10.1016/j.atmosenv.2012.11.036

Sato, K., Jia, T., Tanabe, K., Morino, Y., Kajii, Y., Imamura, T. (2016). Terpenylic acid and ninecarbon multifunctional compounds formed during the aging of $\beta$-pinene ozonolysis secondary organic aerosol. Atmos. Environ. 130, 127-135. https://doi.org/10.1016/j.atmosenv.2015.08. 047

Sauer, F., Schäfer, C., Neeb, P., Horie, O., Moortgat, G.K. (1999). Formation of hydrogen peroxide in the ozonolysis of isoprene and simple alkenes under humid conditions. Atmos. Environ. 33, 229-241. https://doi.org/10.1016/S1352-2310(98)00152-6

Scorch, C., Wissenbach, D. K., Franck, U., Wendisch, M., Schlink, U. (2017). Degradation of indoor limonene by outdoor ozone: A cascade of secondary organic aerosols. Environ. Pollut. 226, 463-472. https://doi.org/10.1016/j.envpol.2017.04.030

Shiroudi, A., Deleuze, M.S. (2014). Theoretical study of the oxidation mechanisms of naphthalene initiated by hydroxyl radicals: The $\mathrm{H}$ abstraction pathway. J. Phys. Chem. A 118, 4593-4610. https://doi.org/10.1021/jp500124m

Sipilä, M., Jokinen, T., Berndt, T., Richters, S., Makkonen, R., Donahue, N. M., Mauldin III, R. L, Kurten, T., Paasonen, P., Sarnela, N. (2014). Reactivity of stabilized Criegee intermediates (sCls) from isoprene and monoterpene ozonolysis toward $\mathrm{SO}_{2}$ and organic acids. Atmos. Chem. Phys. 14, 12143-12153. https://doi.org/10.5194/acp-14-12143-2014

Stangl, C.M., Krasnomowitz, J.M., Apsokardu, M.J., Tiszenkel, L., Ouyang, Q., Lee, S., Johnston, M.V. (2019). Sulfur dioxide modifies aerosol particle formation and growth by ozonolysis of monoterpenes and isoprene. J. Geophys. Res. 124, 4800-4811. https://doi.org/10.1029/2018 JD030064

Sun, J.F., Mei, Q., Wei, B., Huan, L., Xie, J., He, M.X. (2018). Mechanisms for ozone-initiated removal of biomass burning products from the atmosphere. Environ. Chem. 15, 83-91. https://doi.org/10.1071/EN17212

Taatjes, C.A., Welz, O., Eskola, A.J., Savee, J.D., Scheer, A.M., Shallcross, D.E., Rotavera, B., Lee, E.P.F., Dyke, J.M., Mok, D.K.W., Osborn, D.L., Percival, C.J. (2013). Direct measurements of conformer-dependent reactivity of the Criegee intermediate $\mathrm{CH}_{3} \mathrm{CHOO}$. Science 340, 177-180. https://doi.org/10.1126/science.1234689

Truhlar, D.G., Garrett, B.C., Klippenstein, S.J. (1996). Current status of transition-state theory. J. Phys. Chem. 100, 12771-12800. https://doi.org/10.1021/jp953748q

Vereecken, L., Harder, H., Novelli, A. (2012). The reaction of Criegee intermediates with $\mathrm{NO}, \mathrm{RO}_{2}$, and $\mathrm{SO}_{2}$, and their fate in the atmosphere. Phys. Chem. Chem. Phys. 14, 14682-14695. https://doi.org/10.1039/c2cp42300f

Wang, L.Y., Wang, L.M. (2017). Mechanism of gas-phase ozonolysis of sabinene in the atmosphere. Phys. Chem. Chem. Phys. 19, 24209. https://doi.org/10.1039/c7cp03216a

Wang, X., Sun, J., Bao, L., Mei, Q., Wei, B., An, Z., Xie, J., He, M.X. (2019). Mechanisms and kinetic parameters for the gas-phase reactions of 3-methyl-3-buten-2-one and 3-methyl-3-penten-2one with ozone. J. Phys. Chem. A 123, 2745-2755. https://doi.org/10.1021/acs.jpca.8b12025

Ye, J., Abbatt, J.P.D., Chan, A.W.H. (2018). Novel Pathway of $\mathrm{SO}_{2}$ oxidation in the atmosphere: Reactions with monoterpene ozonolysis intermediates and secondary organic aerosol. Atmos. Chem. Phys. 18, 5549-5565. https://doi.org/10.5194/acp-2017-1054

Zhang, H., Yee, L.D., Lee, B.H., Curtis, M.P., Worton, D.R., Isaacman-VanWertz, G., Offenberg, J.H., Lewandowski, M., Kleindienst, T.E., Beaver, M.R., Holder, A.L., Lonneman, W.A., Docherty, K.S., Jaoui, M., Pye, H.O.T., Hu, W., Day, D.A., Campuzano-Jost, P., Jimenez, J.L., ..., Goldstein, A.H. (2018). Monoterpenes are the largest source of summertime organic aerosol in the southeastern United States. Proc. NatI. Acad. Sci. U.S.A. 115, 2038-2043. https://doi.org/10.10 73/pnas.1717513115

Zheng, J.J., Zhao, Y., Truhlar, D.G. (2009). The DBH24/08 database and its use to assess electronic structure model chemistries for chemical reaction barrier heights. J. Chem. Theory Comput. 5, 808-821. https://doi.org/10.1021/ct800568m 